\title{
Knowledge, Attitude, and Behavior toward COVID-19 Prevention on Indonesian during Pandemic
}

\author{
Retno Widowati ${ }^{1,2 \star}$, Albiruni Raushanfikri ${ }^{3}$ \\ ${ }^{1}$ Biology Master Study Program, Graduate School, Universitas Nasional, South Jakarta, Indonesia; ${ }^{2}$ Midwifery Study Program, \\ Faculty of Health Science, Universitas Nasional, South Jakarta, Indonesia; ${ }^{3}$ Faculty of Psychology, Ruhr University Bochum, \\ Bochum, Germany
}

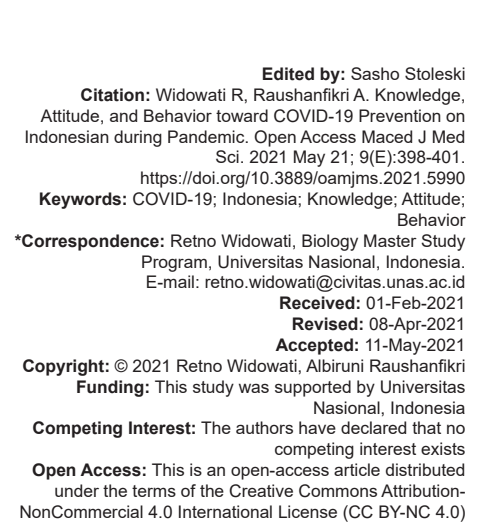

\section{Abstract}

AIM: The objective of the study was to know the sociodemographic factor related to the knowledge, attitude, and behavior toward COVID-19 prevention, during COVID-19 pandemic in Indonesia.

METHODS: Research was conducted through observation with cross-sectional approach and samples were collected using snowball sampling. Research population was the general Indonesian. Questionnaire was used and distributed online for 4 days. Chi-square and regression were used for analysis.

RESULTS: Questionnaire distributed was fulfilled completely by 1167 participants from 30 provinces. Gender has a negative correlation with participants' attitudes and behavior in preventing COVID-19. Age and education were significantly related $(p<0.01)$ to COVID-19 knowledge and had a significant positive effect $(p<0.01)$ on attitude and behavior. Occupation was significantly related $(p<0.01)$ to COVID-19 knowledge. Occupation has a positive effect, but not significantly to attitude and behavior. The province of the participants' residence was not significantly related to COVID-19 knowledge, and it is not significantly on attitude and behavior. Knowledge is highly affected the attitude of preventing COVID-19 $(f=0.36)$

CONCLUSION: Age, education, and occupation significantly related to COVID-19 knowledge. Age and education are positively correlated with attitude and behavior. Knowledge is highly affected the attitude of preventing COVID-19.

\section{Introduction}

Coronavirus disease 2019 (COVID-19) cases in Indonesia have been continuously increased. In March 2, 2020, Indonesia has reported two people who were positive of COVID-19. Until this research report made, the official data issued by the government in May 26, 2020, have reported 415 positive COVID-19, totaling 23,165 people suffering from the disease in which 5877 people recovered from the disease, 1418 people have died due to the disease, 15,870 people in care, 65,748 people were in control, and 12,022 patients were also in control. Although the positive case has decreased compared to 973 positive cases reported in May 21, 2020, the number of people in care has continuously increased everyday [1].

Based on Worldometer, of March 1, 2021, a number of confirmed cases of COVID-19 in the world were 114,999,271; number deaths of SARCoV-2 infection in the world were 2,552,587; number of confirmed cases of COVID-19 in Indonesia were $1,368,069$; number of deaths of SARS-CoV-2 infection in Indonesia were 36,325.

Clinical characteristics of coronavirus disease 2019 in China were fever, $43.8 \%$ of the patients at hospital admission but developed in $88.7 \%$ during hospitalization. The second most common symptom was cough $(67.8 \%)$; nausea or vomiting $(5.0 \%)$ and diarrhea (3.8\%) were uncommon [2]. Hospitalized patients with COVID-19 in Sofia, Bulgaria, had leading clinical signs on hospital admission were fatigue, cough, and fever, $79.0 \%$ of patients had body temperature above $37.5^{\circ} \mathrm{C}$ and $39.9 \%$ of patients had oxygen saturation below $93 \%$ [3]. The most common symptoms of European patients with coronavirus disease 2019 were headache $(70.3 \%)$, loss of smell $(70.2 \%)$, nasal obstruction $(67.8 \%)$, asthenia $(63.3 \%)$, cough $(63.2 \%)$, rhinorrhea $(60.1 \%)$, myalgia ( $62.5 \%)$, respiratory dysfunction $(54.2 \%)$, and sore throat $(52.9 \%)$. Fever was reported by $45.4 \%[4]$.

As the COVID-19 patients in Indonesia has been continuously increased, a question is raised regarding of how the community knowledge, attitude, and behavior concerning COVID-19 prevention during pandemic in Indonesia. Knowledge is the most important domain in forming someone's behavior [5]. Therefore, the knowledge and attitude of most Indonesian people is expected to affect their adherence on their attitude regarding personal protection which eventually produces clinical result. The lack of awareness often indicates ignorant attitude which can affect the preparedness to 
encounter obstacles during pandemic of COVID-19 [6]. Individual's behavior is related to the factors of knowledge and attitude. In addition to be affected by the knowledge and attitude, someone's behavior also refers to the value and norm system adhered [7].

According to the explanation above, this research aimed to know the sociodemography factors which are related to the knowledge, attitude, and behavior of COVID-19 prevention, as well as the effect of knowledge and attitude toward the behavior during COVID-19 pandemic in Indonesia. This research provides essential information for public health stakeholders, especially the ministry and the office of health in making strategy of health promotion to suppress new COVID-19 case in Indonesia and various regions.

\section{Methods}

\section{Sampling}

This observational research was carried out using cross-sectional approach. Samples were collected through snowball sampling technique from May 19 to 22, 2020. The questionnaire was distributed through WhatsApp to the participants.

\section{Research instrument}

The instrument was in the form of online semi-structured questionnaire using the web-based application of SoSci Survey (https://www.soscisurvey. $\mathrm{de} /$ ). If they answered the questionnaire spontaneously, they would have time to answer for 9 min at most.

Research questions related to COVID-19 were adapted from the $\mathrm{WHO}$ [8]. There were total of 12 questions containing of 5 questions about clinical presentation, 3 transmission questions, and 4 prevention questions. The knowledge answered correctly would give score of 2 points, while if it is answered incorrectly, it would give 1 point. The knowledge has ordinal scale. Score more than $50 \%$ would be categorized as good COVID-19 knowledge. There were four questions which measured attitude with 4 Likert scale. The internal stability (Cronbach's alpha) from the attitude was 0.879 . There were five questions measured the behavior of COVID-19 prevention with 4 Likert scale. The internal stability of behavior was 0.706 . The research instruments have fulfilled the reliability and validity to measure the constructs of instruments for measurement [9].

\section{Research ethics}

The confidentiality of research participant information is maintained throughout the study by making the participant information anonymous.
The participation in this survey was voluntary and spontaneously. The data collected would be destroyed 5 years after the end of this questionnaire.

\section{Ethics statement}

The study was performed in accordance with the principles of the Declaration of Helsinki. The questionnaire and collect data procedures of this study were approved by the Committee Ethic on Health Research, Faculty of Public Health, Universitas Hasanuddin, Indonesia.

\section{Data analysis}

Chi-square test was performed to analyze the relationship between the sociodemographic characters and knowledge. The relationship between sociodemography with attitude and behavior was measured by nonparametric correlation with Spearman-Rho given that sociodemography in this study is non-interval scale. Linear regression analysis was used to investigate the effect of knowledge and attitude on behavior if these three variables show a significant relationship. Data analysis was performed using SPSS version 17.0. The level of statistical significance was set at $p<0.05$.

\section{Results}

There was a total 1167 participants completed their sociodemographic data and could be further analyzed. Participants who filled out the questionnaire completely came from 30 provinces in Indonesia.

The lowest knowledge score was 17 while the highest was 24 , with the median of 24 . As many as, $55 \%$ of participants answered all questions correctly. The average value of attitude was $3.622 \pm 0.547$ (minimum 3.5771 and maximum 3.6577). The average value of behavior is $3.429 \pm 0.464$ (minimum 2.6658 and maximum 3.5472). In this study, most participants were female, highly educated, working, aged between 17 and 70 years and mostly $17-28$ years $(43.4 \%)$. A total of $55 \%$ of participants answered all questions correctly. Relationship between the sociodemography and knowledge, the effect of the sociodemography to attitude and behavior is presented in Table 1.

\section{Post hoc result}

Multiple linear regression test was performed and resulting that knowledge and attitudes affected the 
Table 1: Relationship and effect of the sociodemography, knowledge, attitude, and behavior $(n=1167)$

\begin{tabular}{|c|c|c|c|c|c|c|}
\hline \multirow[t]{2}{*}{ Sociodemography } & \multicolumn{2}{|l|}{ Knowledge } & \multicolumn{2}{|l|}{ Attitude } & \multicolumn{2}{|l|}{ Behavior } \\
\hline & $\mathrm{X}_{(\mathrm{n})}^{2}$ & $\mathrm{p}$ & $\begin{array}{l}\text { Correlation } \\
\text { coefficient }\end{array}$ & $\begin{array}{l}\text { Sig. (two } \\
\text { tailed) }\end{array}$ & $\begin{array}{l}\text { Correlation } \\
\text { coefficient }\end{array}$ & $\begin{array}{l}\text { Sig. (two } \\
\text { tailed) }\end{array}$ \\
\hline Gender & $X_{(1)}^{2}=1.990$ & 0.158 & -0.114 & $<0.01$ & -0.183 & $<0.01$ \\
\hline Age & $X_{(9)}^{2(1)}=31.347$ & $<0.01$ & 0.109 & $<0.01$ & 0.143 & $<0.01$ \\
\hline Education & $X_{(3)}^{2^{2(1)}}=14.873$ & $<0.01$ & 0.134 & $<0.01$ & 0.112 & $<0.01$ \\
\hline Occupation & $X_{(6)}^{2}=22.244$ & $<0.01$ & 0.046 & 0.116 & 0.047 & 0.112 \\
\hline Province & $X^{2^{(2)}}=27.975$ & 0.519 & 0.020 & 0.493 & -0.003 & 0.921 \\
\hline
\end{tabular}

behavior. As much as, $12 \%$ of the variance in behavior can be explained through these two predictors. However, the results of multiple linear regression showed that only attitudes had affect behavior significantly $\left(F_{[2.1164]}=76.546, p<0001\right)$ with a strong effect $(f=0.36)$ [10]. In the analysis at the coefficient level of the linear regression model, if the attitude rises by 1 point, then the behavior of preventing COVID-19 will increase by 0.287 points (Table 2 ).

Table 2: Multiple linear regression for the effect of knowledge and attitude on behavior

\begin{tabular}{lllll}
\hline Variable & $\beta$ & SE & Beta & $\mathrm{t}$ \\
\hline Attitude & 0.287 & 0.023 & 0.338 & $12.250^{\star \star *}$ \\
Knowledge & 0.022 & 0.026 & 0.023 & 0.839 \\
\hline $\mathrm{R}^{2}=0.115^{\star \star *}, F_{(2,1164)}=76.546^{* \star *},{ }^{* \star *}$ significant $P<0.001$. & &
\end{tabular}

Simple linear regression test shows that knowledge affected attitude significantly $\left(F_{[2,1165]}=6.29\right.$, $p<0.05$ ) with low effect $(f=0.07)$ [10]. The coefficient of the linear regression model shows that if knowledge increases by 1 point, attitude will increase by 0.081 points (Table 3 ).

Table 3: Simple linear regression for the effect of knowledge toward the attitude

\begin{tabular}{lllll}
\hline Variable & $\beta$ & SE & Beta & $t$ \\
\hline Knowledge & 0.081 & 0.032 & 0.073 & $2.508^{*}$ \\
\hline $\mathrm{R}^{2}=0.005^{*}, F_{(2,1165)}=6.29^{*},{ }^{* *}$ significant $P<0.05$. & & &
\end{tabular}

$\mathrm{R}^{2}=0.005^{*}, F_{(2,165)}=6.29^{*},{ }^{* *}$ significant $P<0.05$

\section{Discussion}

Age and education knowledge had significant relationship to knowledge, and significantly affected the attitudes and behaviors of COVID-19 prevention. The minimum age of participants in this study was 17 years old, which is considered to be an adult according to the notion in Indonesia. Young people also have the potential to ignore the practical knowledge which is not obtained at school or campus. They are also easy to take risks because it is a challenge to disobey, moreover, it is stated in some information that young people are less risk of being infected with COVID-19. It can be explained by the development of risk behaviors in the development of curvilinear age [11]. Getting older, people have useful knowledge for their own health, increasingly positive attitude and behavior to prevent being infected by COVID-19.

Highly educated people were very sensitive about various information continuously reported every day in various media, so they have better in knowledge, positive attitude, and behavior in COVID-19 prevention. Furthermore, the significant positive relationship between education level and COVID-19 knowledge score supports this speculation [12].

There was a significant relationship between occupation and knowledge. Student and people who did not work as participants had lower level of knowledge compared to participants who were already working. It may be caused the environment which plays an important role in exchanging information related to COVID-19 [13].

There was a significant relationship between knowledge and attitude toward behavior, but has weak effect on behavior, otherwise knowledge has a strong effect on attitude. Knowledge is important for the community, because participants who have insufficient knowledge carry negative attitudes toward the epidemic [14]. Behavior also concerns the economic dimension, including the availability of facilities and infrastructure. A person who is behave in a healthy manner will never practice the behavior if there is no economic capacity or the unavailability of facilities, for example, there are no means available to wash hands using soap [7]

These results explain that it is important to improve people's knowledge regarding COVID-19 by focusing on health education to community groups so that it can make the community aware of the pandemic transmission. Thus, it is easier for the government and authorities to handle the prevention and reduce the number of positive new cases of COVID-19 in Indonesia.

\section{Conclusion}

The finding indicates that there was a significant relationship between age, education, and occupation related to COVID-19 knowledge. Age and education are significantly related to COVID-19 attitude and behavior prevention. There was also a significant relationship between knowledge and attitudes toward COVID-19 prevention behavior in Indonesia. There was a significant relationship between COVID-10 knowledge and the people's attitude during this pandemic.

\section{Ethical Clearance}

Ethical clearance taken from Committee Ethic on Health Research, Faculty of Public Health, 
Universitas Hasanuddin, Indonesia, number 6191/ UN4.14.1/TP 01.02/2020.

\section{References}

1. COVID-19 GTPP. Infografis Covid-19; 2020. Available from: https://www.covid19.go.id/p/berita/infografis-covid-21-05juli-2020. [Last accessed on 2020 Sept 26]

2. Guan $\mathrm{W}, \mathrm{Ni} Z, \mathrm{Hu}$ Y, Liang WH, Ou CQ, He JX, et al. Clinical characteristics of coronavirus disease 2019 in China. N Engl J Med. 2020;382(18):1708-20.

3. Popov GT, Baymakova M, Vaseva V, Kundurzhiev T, Mutafchiyski V. Clinical characteristics of hospitalized patients with COVID-19 in Sofia, Bulgaria. Vector Borne Zoonotic Dis. 2020;20(12):910-5. https://doi.org/10.1089/vbz.2020.2679 PMid:33054699

4. Lechien JR, Chiesa-Estomba CM, Place S, Van Laethem Y, Cabaraux $\mathrm{P}$, Mat $\mathrm{Q}$, et al. Clinical and epidemiological characteristics of 1420 European patients with mild-to-moderate coronavirus disease 2019. J Intern Med. 2020;288(3):335-44.

PMid:32352202

5. Notoatmodjo S. IImu Perilaku Kesehatan. Jakarta: Rineka Cipta; 2014.

6. Roy D, Tripathy S, Kar SK, Sharma N, Verma SK, Kaushal V. Study of knowledge, attitude, anxiety \& perceived mental healthcare need in Indian population during COVID-19 pandemic. Asian J Psychiatr. 2020;51:102083. https://doi. org/10.1016/j.ajp.2020.102083

\section{PMid:32283510}

7. Menteri Kesehatan RI. Peraturan Menteri Kesehatan RI Nomor: 2269/Menkes/Per/XI/2011 Tentang Pedoman Pembinaan Perilaku Hidup Bersih Dan Sehat. Jakarta: Menteri Kesehatan Rl; 2011. https://doi.org/10.33373/dms.v7i2.1701

8. WHO. Pertanyaan dan Jawaban Terkait Coronavirus; 2020 Available from: https://www.who.int/indonesia/news/novelcoronavirus/qa-for-public. [Last accessed on 2020 May 26].

9. Taber KS. The use of cronbach's alpha when developing and reporting research instruments in science education. Res Sci Educ. 2018;48(1):1-24. https://doi.org/10.1007/ s11165-016-9602-2

10. Cohen J. Statistical power analysis. Curr Dir Psychol Sci. 1992;1(3):98-101.

11. Steinberg L. A dual systems model of adolescent risk-taking Dev Psychobiol. 2010;52(3):216-24.

PMid:20213754

12. Zhong BL, Luo W, Li HM, Zhang QQ, Liu XG, Li WT, et al. Knowledge, attitudes, and practices towards COVID-19 among chinese residents during the rapid rise period of the COVID-19 outbreak: A quick online cross-sectional survey. Int J Biol Sci. 2020;16(10):1745-52. https://doi.org/10.7150/ijbs.45221 PMid:32226294

13. Keyton J, Caputo JM, Ford EA, Fu R, Leibowitz SA Liu $\mathrm{T}$, et al. Investigating verbal workplace communication behaviors. J Bus Commun. 2013;50(2):152-69. https://doi. org/10.1177/0021943612474990

14. Ilesanmi O, Alele FO. Knowledge, attitude and perception of ebola virus disease among secondary school students in Ondo State, Nigeria, October,2014.PLoS Curr. 2016;8:1.https://doi.org/10.1371/ currents.outbreaks.c04b88cd5cd03cccb99e125657eecd76 PMid:27366583 